Karsten Pedersen*

\title{
The construction of a genre: The case of service information pamphlets in a Danish county
}

\begin{abstract}
From 1999 to 2001 I was head of administrative communication in a local council in Denmark. There I was responsible for authoring and publishing service information pamphlets. I never had any complaints from the citizens who were supposed to read the pamphlets. And that made me worried. So worried that I have now spent a year analysing not only the pamphlets, but also their reception in the target population. In this article I shall make a genre analysis of the service information pamphlet and I shall compare the results of the genre analysis with the basic results of the reception analysis.
\end{abstract}

\section{Creating a genre}

In 1995 the Danish Parliament passed legislation (Act of Parliament No. 380 of 14 June 1995) that was supposed to improve local and regional governmental information to the citizens. One of the reasons why the politicians wanted to increase the information level was a desire to make it possible for the citizens to enter into a democratic dialogue with local and regional government (Andersen 1996: 6; Kommunernes Landsforening [Local Government Denmark] 2002: 10)

The Act obligated local and regional authorities in Denmark to publish information on the services that they offer their citizens:

Sec. 62. The [local or regional] council shall state the contents and scope of the services offered or planned to be offered to the citizens [of the county]. The statement shall be given at least every two years.

\footnotetext{
* Karsten Pedersen

University of Roskilde

Universitetsvej 1

DK-4000 Roskilde

kape@ruc.dk
} 
In addition the statement shall inform citizens of the goals formulated by the council (Indenrigsministeriet, Kommunernes Landsforening,

Amtsrådsforeningen, 1998: 5, my translation).

The legislation inaugurated the creation of a new genre, the service information pamphlet. This article is a case based genre analysis casting light on various aspects of the service information pamphlet.

Even though there are few concrete legal demands as to the design and the contents of the statements, the result has been the publication of a series of relatively identically cast service information pamphlets with variations depending on place of publication, type of information (social, technical, etc.).

This is very close to Bhatia's definition of genre:

Taking genre, after Swales (1981b, 1985 and 1990), it is a recognizable communicative event characterized by a set of communicative purpose(s) identified and mutually understood by the members of the professional or academic community in which it regularly occurs. Most often it is highly structured and conventionalized with constraints on allowable contributions in terms of their intent, positioning, form and functional value. These constraints, however, are often exploited by the expert members of the discourse community to achieve private intentions within the framework of socially recognized purpose (s) (Bhatia, 1993:13)

The last few lines of this definition highlight the notion of genres as dynamic entities. This view is shared by some of the major theorists in the field (Bhatia 2002, 1999, 1993; Göpferich 2000, Swales 1990; Berkenkotter \& Huckin 1995), who point out that genres are constantly (re)negotiated. So the mechanisms employed in maintaining existing genres may also be expected to be present in the creation of a new genre.

That genres are indeed dynamic is emphasised by Bhathia who writes:

[...] genres are not only extremely versatile in that they can be constructed, interpreted and exploited at various levels, they can also appear in interesting combinations, such as mixed, hybrid and embedded forms. (Bhatia 2002:1).

In this paper I will describe the genre that emerged as a result of local and regional governments' legislative obligation to inform the public. I will also discuss the reception of one specific pamphlet by external as well as internal target groups. 


\section{The project}

\subsection{The case study}

The County of Ringkjøbing (CR), which is the westernmost county in Denmark, produces a box of pamphlets. And, in accordance with the law, each pamphlet is revised every two years. In this paper I will use the pamphlet "Service for people with speech, hearing and seeing disabilities"1 (Ringkjøbing Amt 2002f), published by CR as a kind of model pamphlet for the genre analysis. Together with the other six pamphlets in the series and pamphlets from the local Councils of Haslev, Horsens, and Søllerød, the model pamphlet functions as the basis for the analysis.

In order to unfold the textual and social practices (see Fairclough 1998: 133-5; Winther Jørgensen and Phillips 2002: 69) by which the pamphlets were produced I interviewed two county administrative officers and one representative for the field workers central to the production of the pamphlets.

The reception analysis included in the project (Pedersen 2002, 2003a) consisted of eight semi-structured qualitative interviews with members of the target group. I followed Kvale's (1994) approach in order to obtain answers that would give the County detailed knowledge to be used in the further work with the pamphlet. I wanted the interviews to reflect the heterogeneity of the target group, and therefore there are two groups of interviewees. One group of interviewees was a group of users of the services, and the other group was a group of parents of users of the services.

The differences between the results of the interviews in the two groups were small and insignificant compared with the overall findings of the survey. The surveys revealed that only two interviewees had seen the pamphlet before, and of them had read it (Pedersen 2003a). On the other hand, all of the interviewees were well informed about the services of the County and had no need for the pamphlet.

1 My translation. The original title is "Service til personer med tale-, høre-, eller synshandicap". 
34

\section{The making of the genre}

\subsection{Legislation}

As the legislative quote above makes clear, the legislation regarding service information is rather broad. Basically, there are two legislative demands: 1) that the goals of the county council be presented; and 2) that the services be presented to the citizens.

Below is an extract of the goal formulation in CR's pamphlet on service for people with speech, hearing and seeing disabilities:

The Council's goals are:

To let the educational, the supervisory and the therapeutical services take the individual's needs as their point of departure. The services must be of the best possible quality and integrate all important elements

(Ringkjøbing Amt 2002f, my translation).

The services are presented like this:

At the suspicion of hearing impairment the Hearing Clinic carries out an examination and advises on the possibilities of the user, including the option of having a hearing aid fitted (Ringkjøbing Amt 2002f, my translation).

So, on part of the legislators, there were only two constraints on the service information genre. In that light, it seems quite natural that what would emerge from such a general law would be quite diverse but, as mentioned, and as we shall see later, that never proved to be the case.

\subsection{Discussions of the genre}

The various branches of local and regional government and their organisations naturally discussed how to meet the legislative demands. Some of these discussions have resulted in the publication of recommendations co-published by the Ministry of Interior Affairs, Local Government Denmark and the Association of County Councils in Denmark (Indenrigsministeriet, Kommunernes Landsforening, Amtsrådsforeningen 1998). These publications, naturally, must be seen as rather authoritative guidelines that regional and local government can use in order to make sure that they live up to legislative obligations.

Basically, there are three booklets that deal with the service information pamphlets (Indenrigsministeriet, Kommunernes Landsforening, Amts- 
rådsforeningen 1998, Helth 1996, Petersen and Schnoor 1995). All of them are produced by the same consultancy firm, but they focus on different aspects of work with the information pamphlets. Some recommendations are practical, detailing how to make sure that the pamphlets are structured in a similar way, what to include in the pamphlets, etc.

These publications also recommend that similar structures are used for pamphlets belonging to the same area (social, technical etc.).

There are also recommendations on the language used in service information pamphlets in order to convey professional knowledge to a non-professional audience.

In addition to the more authoritative recommendations, there are also a number of books and booklets dealing with administrative language in more general terms. All of these publications identify the same two main problems, namely that administrative language is too formal and that administrative writers find it difficult to leave out officialese and thus address citizens in 'their own language'. This is highlighted by Møller and Hansen who write that:

[Technical terms] are dangerous to communication. In certain circles they are quickly accepted on equal terms with the most common words of the language, and soon the people moving in these circles have lost the ability to determine whether one of the words that they use all the time belongs to standard language (Møller and Hansen 1998: 6, my translation).

In addition to this, it is also quite common to recommend that administrative staff use simple syntax, direct address and dialogical constructions in their texts. We see an example of this in the information policy of the CR:

In its information work and its letters, the County invites to dialogue by telling the reader: Who is the agent (the council, the committee, the director, the nurse, the class teacher, the applicant, the citizen, etc). In other words: Do not hide behind systems and institutions.

[...]

\section{Do not write}

In reference to your letter of June 10 1998, we shall hereby inform you that ... 


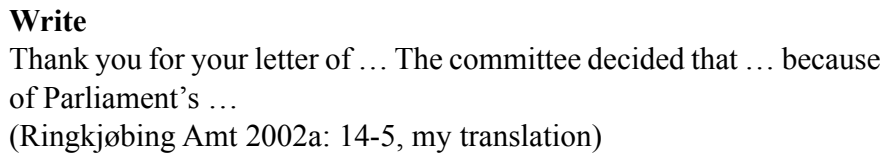

The overall recommendations as well as the CR's information policy stresses the importance of simple syntax, few (if any) passives, few (if any) nominalisations: "A safe road to a more active language is to change nouns to verbs. Make sure that you avoid nouns ending on -ing, -ning, -else, -ende, -sel. (Ringkjøbing Amt 2002a: 14, my translation,). Also the more general recommendations on written communication stress this:

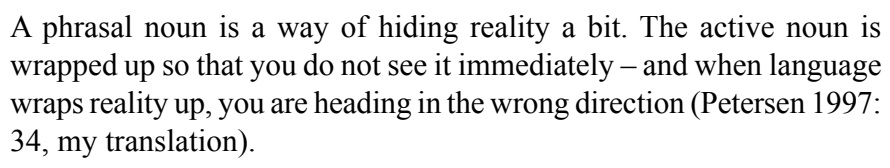

The recommendations can be summarised like this: use direct address, use active voice and make sure that you use words that the target group will understand.

\subsubsection{Contents, language and the order of things}

The text is basically a listing of the services that the County offers citizens with the disabilities in question, and like all the other pamphlets in the series, the outline of the pamphlet follows a schema starting off with a headline, then a formulation of the Council's goals in the area(s), and subsequently a listing of the services offered to people with speech, hearing and seeing disabilities, respectively. Each of the three sections is arranged so that they first mention the types of services (e.g. education), and then each type of service is split into services to children and services to adults. The second last section of the pamphlet is a list of specific service goals, e.g.:

That not later than one month after being examined, the user receives the counselling required by him or her (Ringkjøbing Amt 2002f, my translation).

Finally, there is a list of addresses and telephone numbers.

The overall structure of the other pamphlets in the series is similar to the one described above. The service information pamphlets published by the Councils of Haslev and Søllerød follow a similar structure. 
The Council of Horsens, however, has chosen to publish all the service texts in a booklet that is posted to the citizens (Horsens 2001; Horsens 2002). The booklet is directory-like and the texts are brief, often bulleted lists that give an overall impression of the services presented. The booklet is ordered by service type and each service is described briefly, and at the end of the description one can see all the relevant addresses and telephone numbers.

\subsection{Genre analysis ${ }^{2}$}

\subsubsection{Form and medium}

The pamphlets produced by the Department for Education and Social Affairs were produced by small groups of people with special knowledge of the subject matters relevant for each pamphlet. The groups were all referring to a county administrative officer with the final say on the pamphlets. In that way it was possible for the central administration of the County to maintain a certain degree of power over the production process while drawing on the expertise of the people working with the target group.

The municipality of Søllerød used to publish a newspaper with the service information in the shape of newspaper articles (Municipality of Søllerød 1999).

Some local government administrations have chosen to print the pamphlets themselves. Thereby they are able to update the pamphlets within hours (Elmelund and Pedersen 1999, Hasle Kommune 2003a).

Some local and regional government administrations have chosen to publish a booklet (this is e.g. done by the Council of Horsens (see 3.2.1 above)) containing units of information not unlike what is found in the pamphlets. The books are distributed to each household and are revised every two years.

There is a tendency that information on pricing and sometimes telephone numbers is not included in the publications that have a low fre-

2 I base my genre analysis on pamphlets in the series published by the CR's department for education and social matters, on similar pamphlets, published by other counties and on pamphlets dealing with matters social published by local councils in Søllerød, Haslev, Køge and Ringsted. 
quency of publication. The reason for this is that rates and telephone numbers are subject to change, and changes will render some of the information in the pamphlets obsolete or even wrong. Some Councils, e.g. the Council of Haslev, update their pamphlets twice a year or whenever there is a change (Elmelund and Pedersen 1999, Hasle Kommune 2003a).

The CR has chosen to publish a series of glossy flyer type pamphlets that are updated every two years. The first two editions were rather generous on information such as pricing and telephone numbers (interview md17/5, 2002), but now they contain only a few telephone numbers and the administrative staff tries to minimise the use of figures that might become subject to change ${ }^{3}$.

\subsubsection{Communicative purpose}

The service information pamphlets in this series are intended to serve internal as well as external communicative purposes.

Internally, the pamphlets can be seen as a means to ensure that the goals are fulfilled. Externally, the pamphlets serve the purpose of informing the general public. The CR divided the external target group into two main groups, 1) users and their relatives and 2) interested citizens that are all thought to belong to the pamphlets' target group:

That is where the concept of the interested citizen comes in. Because that is such a broad definition of the target group, it is supposed to reach everybody, users, family, field workers, citizens in general, and interested citizens, and ... (interview MD 17/5, 2002).

In addition, the pamphlets can be seen as an integral part of informing and controlling staff members working with the users of the services. Informing them in the sense that the pamphlets provide information that also staff members might want to use (Interview HK 20/6, 2002), and controlling them in the sense that the information in the pamphlets also can be seen as rules that staff will have to follow when advising users or their relatives:

3 Even so, my interviews with users of the services revealed that a certain figure had been changed (interview 1-4, 20. june, 2002). 
Interviewer: But it seems that you are also using it [the pamphlet] in a rather internal way.

Interviewee: That is definitely because we would like it to be our way of controlling budgets and degree of goal fulfilment. ... We want to use this [the pamphlets] as external information and as a kind of internal toolbox (interview JS 17/5, 2002).

Even if the county administration would like the pamphlets to be internal tools as well as external vehicles of information, the overall communicative purpose is that of informing the citizens, since that is what the legislation deals with. Note in that connection that the law does not specify other target groups than 'the citizen' (see the opening quote), making for quite a heterogeneous target group. This naturally explains the CR's decision to include into their target group definition the concept of 'the interested citizen' (see above), thus emphasising the overall communicative purpose of informing the general public.

\subsubsection{Situation/context}

The service information pamphlets from the CR's Department for Education and Social Affairs enter into any number of contexts. First of all they belong to the host of pamphlets produced in all kinds of governmental administrative frameworks, secondly they are part of the local framework in Ringkjøbing, thirdly they are part of the series published in the Department for Education and Social Matters (see Göpferich who mentions the fact that personal authorship and organisational factors will influence the wording of a text (Göpferich 2000: 231-232)). In addition, the reception of the pamphlets will vary depending on the target population (staff, users, relatives, social practices, etc.).

The pamphlets are distributed to schools, libraries, city halls, and the institutions where the supposed receivers will meet the CR's services.

\subsubsection{Move structure}

The move structure of the service information pamphlets looks like this: 


\section{Legislation}

\section{Goal formulation}

The goals are rather general statements listing the political goals in the various specific areas dealt with in the different pamphlets. The CR does it like this:

The council's goals are:

- To let the educational, the supervisory and the therapeutical services take the individual's needs as their point of departure. The services must be of the best possible quality and integrate all important elements. (Ringkjøbing Amt 2002f, my translation)

The local Council of Haslev formulates its goals in more general terms:

The council's goal for the services offered by the Council of Haslev is that each citizen experiences his of her dealings with the administration as uncomplicated and pleasant, and that the citizen views the Council's administrative staff as excellent and competent professionals (Council of Haslev, 2003a, my translation).

\section{Obligatory moves}

\section{Listing the services available}

The services are either presented in prose (CR) or as bulleted lists (Haslev, Horsens).

\section{Listing the obligations of the citizens (if applicable)}

"Remember to inform the administration if your social or economic situation changes" (Council of Haslev 2003a, my translation).

\section{Addresses and telephone numbers}

The CR lists a large number of addresses and telephone numbers on the back of each pamphlet, but since this information can be found elsewhere in the booklet produced by the Council of Horsens, they can be a little bit more imprecise:

Refugee/immigrant council:

At: The refugee/immigrant center, city hall

(Council of Horsens 2001: 44, my translation)

There is no obligatory sequence involved, even if there seems to be a preference for the sequence indicated above. 


\section{Optional moves}

\section{Establishing the field}

Service information pamphlets with a goal formulation at the beginning use the goal as a way of establishing the field. Pamphlets that do not have the goals at the beginning sometimes have a paragraph detailing the contents of the pamphlet. The Horsens booklet dedicates some space to a "Readers' guide" (Council of Horsens 2001: 16, my translation).

Paratextual metatext

The CR does not use this move (Ringkjøbing Amt 2002f), whereas the Council of Haslev does (Council of Haslev 2003a).

A paratextual metatext is a text that identifies the pamphlet as a service information pamphlet, and such text is very often used on the front page of pamphlets. Most often it comes in the form of a general headline reading "Service information". The County of Haslev uses such a metatext (Haslev Kommune 2003a, Haslev Kommune 2003b), whereas the CR does not (Ringkjøbing Amt 2002f).

\subsubsection{Rhetorical strategies}

In actual use the pamphlets from the CR's Department for Education and Social Matters turn out to not comply with the recommendations for language use (see 3.2.1). In the pamphlet under scrutiny here, we see that throughout:

Service to people who have a speech, hearing or seeing disability is provided by local as well as regional authorities (Ringkjøbing Amt 2002f, my translation).

In a sense all the basic plain language recommendations are violated here. The pamphlet uses passive voice (marked in bold face), and there is no use of direct address (none of the seven pamphlets in the CR's series uses direct address). The texts from Horsens (Horsens Kommune 2001, 2002), Haslev (Haslev Kommune 2003a, 2003b), and Søllerød (Søllerød Kommune 1999) Councils all make extensive use of dialogical elements such as active voice and direct address. 
42

\section{The pamphlets and the receivers}

As mentioned there are three target groups for the pamphlet: staff members, the interested citizen and users and their relatives. From my interviews with representatives of the latter group it is clear that they do not recognise the service information pamphlet as member of a particular genre, basically because they do not know the pamphlets (Pedersen 2002, 2003a, 2003b). This is not only a genre analytical problem, but also a legal problem. It is an analytical problem in the sense that there is no way of ascertaining whether or not the communicative purpose of the pamphlets is fulfilled. This is emphasised by Göpferich (2000) when she says that we do not even know if the perpetuation, by means of imitation, of a genre ensures the fulfilment of the communicative purpose of that genre:

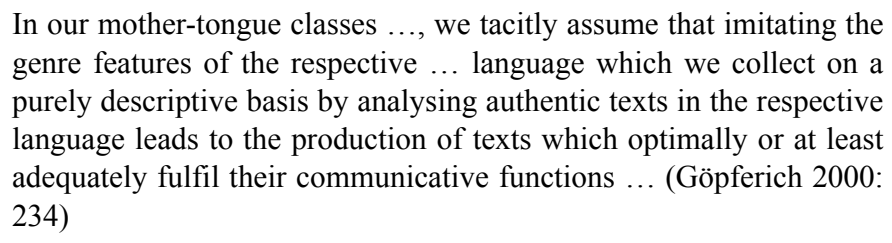
genre features of the respective ... language which we collect on a purely descriptive basis by analysing authentic texts in the respective language leads to the production of texts which optimally or at least adequately fulfil their communicative functions ... (Göpferich 2000: 234)

It is a legal problem in the sense that legislation demands that the council inform its citizens, but my interviews suggest, the pamphlets do not get beyond the desks of the administrators that work with them. Thereby the pamphlet does not even get near the realisation of its communicative purpose, let alone the realisation of the goals of the legislators.

In my interviews I asked the informants to read either the original service information pamphlet or a version that adheres to the linguistic recommendations about direct address, active voice, etc., mentioned earlier (the reception analysis is described in more detail in Pedersen 2002). It was clear from this confrontation with actual texts that the receivers found the changed version much more appealing, suggesting that the $\mathrm{CR}$ would benefit from making their pamphlets somewhat more dialogical. Such a change, however, would not change anything in relation to the most serious problem of them all: that very few people seem to read the pamphlets. 


\section{Conclusions}

Right from the start the writers of the service information pamphlets have been met with recommendations that have shaped the pamphlets. The result is that the pamphlets share a "set of communicative purposes" (Bhatia 1993: 13) and a number of conventions and constraints.

The main communicative purpose of the service information pamphlets is to inform the citizens of counties (or the citizens belonging to a local council) of the services available to them. This is also true of the CR's pamphlets, but, as the survey indicates, the citizens (or at least the members of the target group) are not informed by the pamphlets ${ }^{4}$. The survey is inconclusive as to the reason for this, but it does seem fair to assume that the fact that all of the interviewees are very well informed of the services in the CR has something to do with it. One could suspect that the target population, because it does not need it, ignores the information made available in the pamphlets.

The second communicative purpose, to inform CR staff, seems to be met. Therefore it would be interesting to try to find out what it is that keeps staff members from handing out copies of the pamphlet to their clients, and also to dig deeper into the internal use of the pamphlets in general.

The conventions and constraints make the different pamphlets look similar. This means that it is possible for the target group as well as the producers to recognise a given text as a service information text.

The service information pamphlets are supposed to have a democratic effect; they are supposed to enable the citizens to enter into a democratic discussion with the members of the council as well as the County's administrative staff. In order to achieve this effect, it is not necessary for the publishers of the pamphlets to ensure that each citizen has read all the pamphlets. Judging from my interviews, it might be enough to ensure that field workers pass on their professional knowledge to the citizens entitled to specific services.

4 A group of students working with the Municipality of Copenhagen (Hoffmann et al. 2002) came to the same conclusion, so this is not limited to the CR. 


\section{References}

Andersen, V.N., 1996: Udbredelsen af nye styresystemer i de danske kommuner. Ålborg University. Ålborg.

Berkenkotter, C./T.N. Huckin, 1995: Genre Knowledge in Disciplinary Communication: Cognition - Culture -Power. New Jersey: Lawrence Erlbaum Associates.

Bhatia, V., 2002: Genres in Business Contexts". Plenary presentation at the ABC Conference "Business Communication across Contexts, Cultures and Continents", The Århus School of Business, Århus 22-25 May 2002.

Bhatia, V., 1999: Integrating Products, Processes, purposes and participants in professional writing. In Candlin, C. N./Hyland, K. (eds.), Writing: Texts, Processes and Practices. London: Longman.

Bhatia, V., 1993: Analysing Genre -Language Use in Professional Settings. London: Longman.

Bülow-Møller, A.M./Pedersen, K. 1998: The View from the Bridge - Text analysis for Translators and Other Communicators. Copenhagen: Samfundslitteratur.

Elmelund, J./Pedersen, K. 1999: Serviceinformation i Haslev Kommune. In $Q$ Nyhedsbrev 13. Slagelse.

Göpferich, S., 2000: Analysing LSP Genres (Text Types): From Perpetuation to Optimization in Text(-type) Linguistics. In Trosborg, A. (ed.), Analysing Professional Genres. Amsterdam/Philadelphia: John Benjamins.

Haslev Kommune, 2003a: "Generelt".

Haslev Kommunne, 2003b: Akutboliganvisning. Halsev Kommune.

Helth, P., 1996: Giv brugerne klar besked - serviceinformation til borgerne. Kommunernes Landsforening [Local Government Denmark].

Hoffmann, R. A. et al. 2002: Offentlig kommunikation - et eksempel på kritisk diskursanalyse af offentlig formidling. Final BA-project, Roskilde University.

Horsens Kommune 2001: Borgerhåndbog 2001.

Horsens Kommune, 2002: Borgerhåndbog 2001.

Indenrigsministeriet [Ministry of Interior Affairs], Kommunernes Landsforening [Local Government Denmark], Amtsrådsforeningen [Association of County Councils] 1998: Serviceredegørelser: en rapport om serviceinformation til borgerne [Service Statements. A Report on Service Information to Citizens]. Copenhagen.

Jørgensen, M.W./Phillips, L. 2002: Discourse Analysis as Theory and Method. London: Sage.

Kommunernes Landsforening [Local Government Denmark] 2002: Kommunalpolitik. Kommunernes Landsforening. Copenhagen

Kvale, S., 1994: InterView. En introduktion til det kvalitative forskningsinterview. København: Hans Reitzels Forlag. 
Lov [Act of Parliament] nr. 380 af 14. juni 1995: Www.retsinfo.dk, http://147.29.40.91/ SHOWF_A744409750/925\&A19950038030REGL\&0001\&000001.

Møller, B./Hansen, E. 1998 [1981]: Og uden omsvøb, tak. Copenhagen: Statens Information.

Pedersen, K. 2002: Communicating to heterogeneous target groups. Paper given at 23rd Conference and General Assembly, IAMCR, Barcelona 21-26 July 2002.

Pedersen, K.2003a: Evaluering af serviceinformationer udsendt af Skole og Social, Ringkjøbing Amt. Roskilde University, Roskilde (in press).

Pedersen, K. 2003b: When Authorities Communicate - Democracy and Local and Regional Authorities. In Nikula, K. (ed.), Text, Bild, Samhälle. Tampere (in press).

Petersen, C./Schnoor, L 1995: Man skal love hvad man holder: en pjece om serviceinformation på celdreområdet. Kommunernes Landsforening/Local Government Denmark, Copenhagen.

Petersen, T., 1997: Skriv let - og ej med ncesen i sky, Copenhagen: Frydenlund/Media.

Ringkjøbing Amt 2002a [the County of Ringkjøbing]: Ringkjøbing Amts informationspolitik. Ringkøbing.

Ringkjøbing Amt, 2002b: Service til personer, der har begrcenset arbejdsevne. Ringkøbing.

Ringkjøbing Amt 2002c: Serviceinformation til børn og unge med sociale, adfcerdsmcessige og/eller psykiske problemer. Ringkøbing.

Ringkjøbing Amt 2002d: Serviceinformation til personer med autisme og andre beslaegtede udviklingsforstyrrelser. Ringkøbing.

Ringkjøbing Amt 2002e: Service til mennesker med et misbrug og mennesker med scrlige sociale problemer. Ringkøbing.

Ringkjøbing Amt 2002f: Service til personer med tale-, høre-, eller synshandicap. Ringkøbing.

Ringkjøbing Amt 2002g: Service til personer med sindslidelser. Ringkøbing.

Ringkjøbing Amt 2002h: Service til personer med erhvervet hjerneskade. Ringkøbing.

Ringkjøbing Amt 2002i: Service til personer, der er fysisk handicappede. Ringkøbing.

Ringkjøbing Amt 2002j: Service til personer der er udviklingshcemmede. Ringkøbing.

Swales, J.M.1990: Genre Analysis: English in Academic and Research Settings. Cambridge: Cambridge University Press.

Søllerød Kommune 2003: http://www.sollerod.dk/dept.asp?page=dept\&objno=1740 (January 28, 2003).

Søllerød Kommune 1999: Serviceinformation. 
